\title{
Political deadlock leaves scientists frustrated
}

\section{MUNICH}

While Germany's political parties struggle to set up a new government, scientists are left with little hope for more flexible regulations on stem-cell and biotechnology research.

The federal elections on 18 September led to a political impasse unique in Germany's post-war history. Neither Chancellor Gerhard Schröder's Social Democrat-Green coalition government nor the Christian Democrat-Liberal opposition led by Angela Merkel reached the necessary majority to elect a chancellor and form a government. As all parties have ruled out a coalition with the fifth force in parliament - the new Left Party - Germany's established political forces must hammer out another alliance.

At this stage, the most likely variant is a 'grand coalition' of Social Democrats (SPD), nicknamed 'red', and the 'black' Christian Democrats (CDU and CSU). But the rancorous power struggle between Schröder and Merkel over who would lead such an alliance is still threatening its creation.

A two-party government would be unlikely to produce any radical science policies, however. Under a grand coalition, research budgets would probably increase only modestly, as they did under the previous SPD-Green government - although the responsibilities for science and education could be simplified. Currently, these are split between central government and the 16 state governments.

\section{Call for change}

Such reform would give universities and research councils more financial freedom and is "urgently needed", according to Wilhelm Krull, secretary-general of the Volkswagen Foundation, Germany's largest private research funding agency. But for many researchers the priority is the country's strict rules on stem-cell and transgenic-plant research, which they believe are holding back science in Germany.

${ }^{\alpha}$ There's clearly a need to change these overly restrictive laws," says Ferdinand Hucho, a biochemist at the Free University in Berlin. Hucho is also the main author of a recent report by the Berlin-Brandenburg Academy of Sciences, which highlights various German weaknesses in biotechnology and the life sciences.

The two major parties are deeply split over these issues, and few believe that things will get

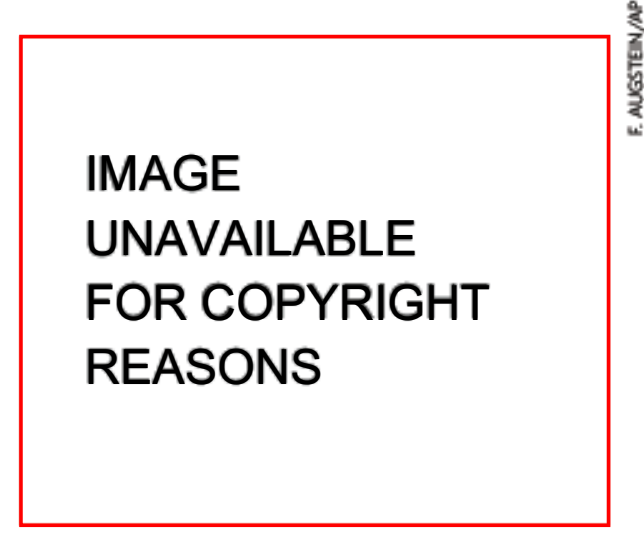

Gerhard Schrōder (right) and Angela Merkel's parties are split over stem-cell research issues.

any better. In particular, the CDU candidate for the science ministry, Annette Schavan, a practising Catholic, is thought to be unlikely to touch existing restrictions in ethically charged areas of science.

The Liberal Free Democratic party (FDP), which won $10 \%$ of the vote, is the only party unambiguously in favour of stem-cell research - including therapeutic doning - and plant biotechnology. Schröder has been courting the FDP heavily, but the 'yellow' party and its leader Guido Westerwelle have said they will not help a red-green-yellow 'traffic light' coalition into power.

Another possible, but unlikely, alliance is what has been dubbed a 'Jamaica' coalition of Christian Democrats, FDP and Greens. The implications for research are unclear, although most scientists admit that the Greens' sevenyear involvement in power has been less of a problem for science than many expected (see Nature 436, 1065; 2005).

Whatever government finally materializes, many scientists in Germany believe that support for specific directions in science is becoming a cross-party question, rather than the domain of single political groups. But they remain frustrated by the legal wrangling surrounding certain ethical issues. "The one thing I really wish," says Wieland Huttner, a director at the Max Planck Institute of Molecular Cell Biology and Genetics in Dresden, "is that science policies could be shaped by scientists, medics and engineers, and less by law experts."

Quirin Schiermeier 